\title{
PROGRAM PELATIHAN PEMBUATAN ALAT PERAGA MATEMATIKA YANG INTERAKTIF BAGI GURU SD SE-GUGUS 01 KECAMATAN PUNGGING
}

\author{
Ririn Febriyanti, Slamet Boediono, Esty Saraswati NH \\ Pendidikan Matematika, STKIP PGRI Jombang \\ Email : ririnfebriyanti280282@gmail.com
}

\begin{abstract}
The training program for making mathematics teaching aids held at SDN Kembangringgit 2, Kembangringgit village, Pungging district, Mojokerto regency. Generally, this training aims to increase creativity and students' enthusiasm for learning mathematics. The main objectives of this training are (1) to establish good relations with schools, (2) to make optimal use of mathematics teaching aids, (3) to provide training on how to make mathematics teaching aids and increase comprehension in mathematics by using mathematics teaching aids. While the target of this mathematics teaching aids training were teachers of elementary school in district of Pungging, Mojokerto regency. The approach used when delivering training matter was the discovery. In discovery approach, student find how to solve the problem themselves. While the methods that we used are lecture, discussion, and demonstration. The advice in this article is teachers should develop their abilities and understanding related to the development and application of teaching aids continuously.
\end{abstract}

Keywords : Training, Teaching aid, Mathematics learning

\section{PENDAHULUAN}

Adanya pendekatan teacher centered menyebabkan bergesernya paradigm matematika dari "Strict body of knowledge" menuju matematika sebagai aktivitas kehidupan (Ibrahim dan Suparni, 2009). Matematika sebagai "Strict body of knowledge" meletakkan dasar bahwa siswa adalah objek yang pasif karena yang diutamakan adalah "knowledge of mathematics", sehingga guru menjadi pusat pembelajaran, sedangkan siswa diharapkan mampu meniru kemampuan matematika yang guru ajarkan (Masamah, 2017).

Agar pendekatan teacher centered dapat diterapkan di kelas, guru harus memiliki kemampuan yang dibutuhkan. Hal ini sejalan dengan yang dinyatakan dalam UndangUndang Republik Indonesia Nomor 20 tahun 2003 tentang sistem pendidikan nasional disebutkan bahwa jabatan guru sebagai pendidik merupakan jabatan profesional. Hal ini berarti guru dituntut untuk melaksanakan tugasnya secara profesional.

Untuk menunjang pelaksanaan tugas guru, Arsyad (Murdiyanto dan Mahatma, 2014) menyatakan bahwa dalam proses belajar mengajar ada dua unsur yang sangat penting, yaitu metode mengajar dan media pembelajaran. Oleh karena itu, peningkatan kompetensi guru dapat dilakukan dengan mengadakan pelatihan. Pelatihan mengandung maksud untuk memotivasi serta memperbaiki kinerja, cara pembelajaran, dan ilmu yang dimiliki guru.

Sebagai langkah awal dalam menggunakan alat peraga matematika, guru harus meyakinkan diri bahwa siswa mengetahui nama dan penggunaan bagian alat peraga yang berbeda. Selain itu, siswa harus bisa memperagakan sekaligus menjelaskan teknik penggunaan alat peraga tersebut. Sehingga siswa termotivasi dalam belajar menggunakan alat peraga. Dalam pengajaran matematika, alat peraga mempunyai kedudukan yang penting diantaranya: (1) kemampuan untuk meningkatkan persepsi; (2) kemampuan untuk meningkatkan pengertian; (3) kemampuan untuk meningkatkan transfer (pengalihan ) belajar; (4) kemampuan untuk memberikan penguatan (reinforcement); (5) kemampuan untuk meningkatkan retensi (ingatan).

Adapun masalah yang dihadapi oleh sekolah mitra sebagai berikut, 1) siswa tidak memperhatikan apa yang disampaikan oleh guru, 2) proses pembelajaran kurang menarik yang menyebabkan siswa bosan, 3) hanya sedikit bahan pelajaran yang sudah disampaikan guru yang dipahami oleh siswa, 4) metode mengajar kurang bervariasi, hanya komunikasi verbal melalui penuturan guru, 5) kurangnya minat belajar siswa terhadap mata pelajaran matematika. Hal ini mendorong 
penulis untuk mengadakan pelatihan alat peraga matematika yang interaktif kepada guru se-gugus 01 Kecamatan Pungging, Kabupaten Mojokerto.

\section{METODE}

Pelatihan pembuatan alat peraga matematika yang interaktif dilakukan melalui beberapa tahapan pelaksanaan kegiatan yang dapat dijelaskan sebagai berikut:

1. Persiapan dan pembekalan

Mekanisme pelaksanaan kegiatan pelatihan alat peraga matematika meliputi tahapan berikut ini:
a. Penyiapan lokasi sekolah mitra pelatihan pembuatan alat peraga matematika.
b. Koordinasi dengan pihak-pihak yang terkait.
c. Perekrutan mahasiswa.
d. Pembekalan mahasiswa.

\section{Pelaksanaan}

Program yang akan dilaksanakan adalah program peningkatan profesionalisme kemampuan guru dalam penggunaan alat peraga matematika. Metode yang digunakan dalam pelatihan pembuatan alat peraga matematika adalah teknik pembelajaran kelompok disertai praktek alat peraga matematika. Untuk memantapkan materi pelatihan, maka pembelajaran disertai praktek akan dilakukan oleh mahasiswa bersama-sama dengan kelompok sasaran.

Metode yang digunakan dalam pelaksanaan pelatihan ini adalah:

a. Ceramah dan tanya Jawab Metode ini dipilih untuk membangkitkan motivasi guru dalam membuat alat peraga yang interaktif

b. Demontrasi

Metode ini dipilih untuk menjelaskan suatu proses kerja secara bertahap sehingga dapat memberikan kemudahan bagi guru untuk mencermati proses pembuatan dan penggunaan alat peraga tersebut.

c. Latihan/praktek

Pada metode ini peserta mempraktekkan penggunaan alat peraga dengan bimbingan mahasiswa Matematika STKIP PGRI Jombang.

3. Evaluasi

Kegiatan evaluasi dilakukan secara langsung oleh pelaksana. Evaluasi berupa hasil kerja atau respon dari peserta (guru mitra) terhadap penggunaan alat peraga matematika dalam pembelajaran matematika. Proses evaluasi dilaksanakan untuk mengetahui kekurangan dan kendala dalam pelaksanaan kegiatan.

\section{Refleksi}

Refleksi dilakukan bersama antara pelaksana dan peserta (guru mitra). Hal ini dilakukan untuk mengetahui seluruh proses pelaksanaan kegiatan.

\section{HASIL DAN PEMBAHASAN}

Adapun hasil dari pelaksanaan kegiatan ini dijabarkan sebagai berikut:

1. Persiapan dan Pembekalan

Kegiatan-kegiatan yang dilakukan pada tahap persiapan dan pembekalan adalah sebagai berikut.

a. Penyiapan lokasi sekolah mitra pelatihan pembuatan alat peraga matematika. Pelaksanaan tahap ini didahului dengan survey lokasi sekolah.

b. Koordinasi dengan pihak-pihak yang terkait. Pada tahap ini dilakukan pengiriman surat serta koordinasi dengan pihak-pihak yang terkait dalam agenda pelatihan ini yaitu dosen yang terlibat dengan ketua gugus 01 kecamatan Pungging.

c. Perekrutan mahasiswa

Pada tahap ini, mahasiswa terlibat dalam proses pembuatan dan presentasi media pembelajaran matematika.

d. Pembekalan mahasiswa

Pada tahap pembekalan ini dosen mengarahkan mahasiswa untuk menyiapkan sebaik mungkin pelatihan yang dilaksanakan.

2. Pelaksanaan

Kegiatan pelaksanaan merupakan kegiatan implementasi program. Kegiatan- 
kegiatan yang dilakukan dalam implementasi program adalah sebagai berikut.

a. Memberikan pengenalan kepada guru-guru terkait alat dan bahan yang dapat digunakan untuk pembuatan media pembelajaran matematika. Kegiatan ini dilakukan dengan memberikan bimbingan dan pelatihan terkait dengan cara pembuatan alat peraga matematika bagi para guru.

b. Meningkatkan pengetahuan dan keterampilan para guru tentang pembuatan media pembelajaran matematika yang interaktif. Kegiatan ini dilakukan melalui pemberian pelatihan pembuatan media pembelajaran interaktif matematika dan cara penggunaannya. Kegiatan pelaksanaan pemberian teori dilakukan dalam satu hari, pada tanggal 30 Maret 2019 bertempat di SDN Kembangringgit 2.

c. Mendemonstrasikan media pembelajaran matematika yang telah dibuat dari hasil pelatihan.

\section{Evaluasi}

Evaluasi dilakukan terhadap kualitas produk yang dihasilkan. Produk yang dihasilkan dalam kegiatan ini adalah media pembelajaran matematika interaktif. Evaluasi juga dilakukan terhadap kemampuan guru dalam menyusun media pembelajaran matematika interaktif dan implementasinya dalam pembelajaran matematika.

\section{Refleksi}

Refleksi dilakukan terhadap kegiatan yang telah dilaksanakan. Hal ini dilakukan semata-mata untuk mengetahui kekurangankekurangan atau kelebihan-kelebihan terhadap kegiatan yang telah dilakukan dalam rangka menetapkan rekomendasi terhadap keberlangsungan atau pengembangan kegiatankegiatan berikutnya. Hasil refleksi perlu dilakukan untuk membantu meningkatkan penguasaan guru terhadap ilmu pengetahuan terutama dalam penerapannya pada pembelajaran matematika.

Contoh Alat peraga Interaktif yang digunakan, yaitu sebagai berikut.
1. Kotak Buta Hitung (Kotak Bukit Taksiran Hitungan)

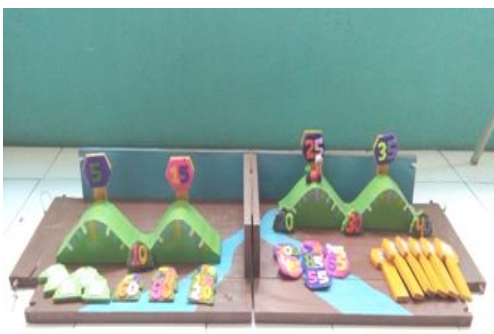

Gambar 1. Kotak Buta Hitung

2. BilBul Box (Box Bilangan Bulat)

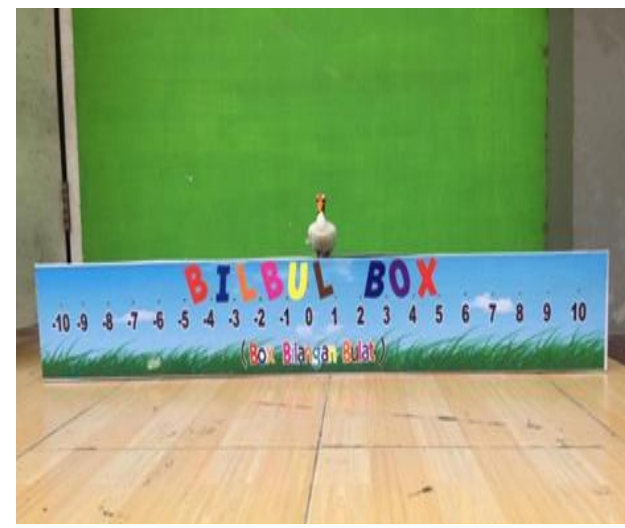

Gambar 2. Box Bilangan Bulat

3. Gedung PKB (Penyelesaian KPK dan FPB)

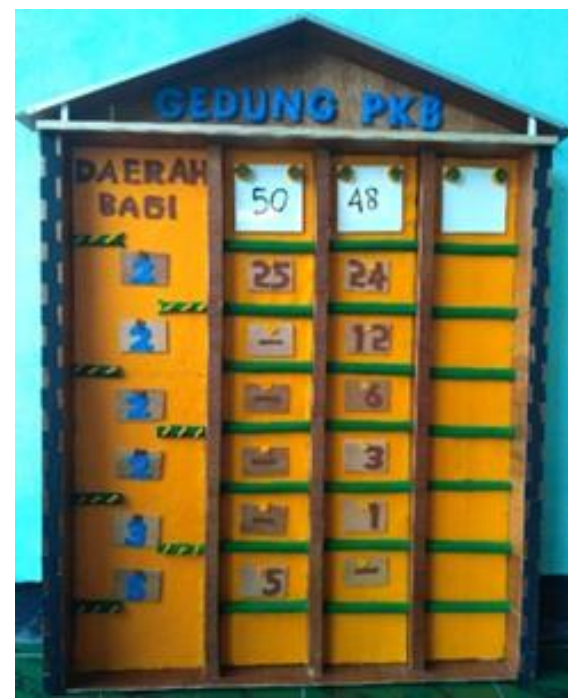

Gambar 3. Gedung PKB

4. Gear Multipication (Perkalian Geer) 
PRINSIP Pendidikan Matematika

Volume 2, Nomor 1, November 2019

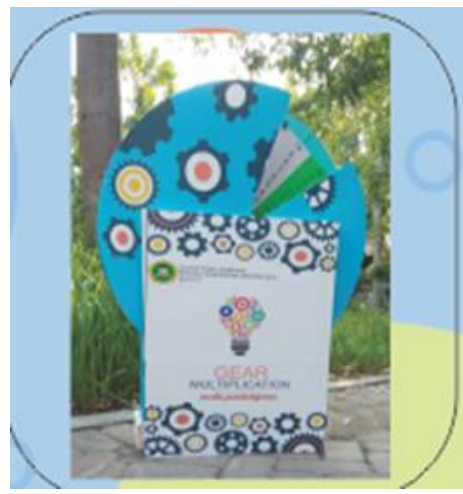

Gambar 4. Perkalian Geer

5. Papan Nangka (Papan Penarikan Akar Pangkat Dua)

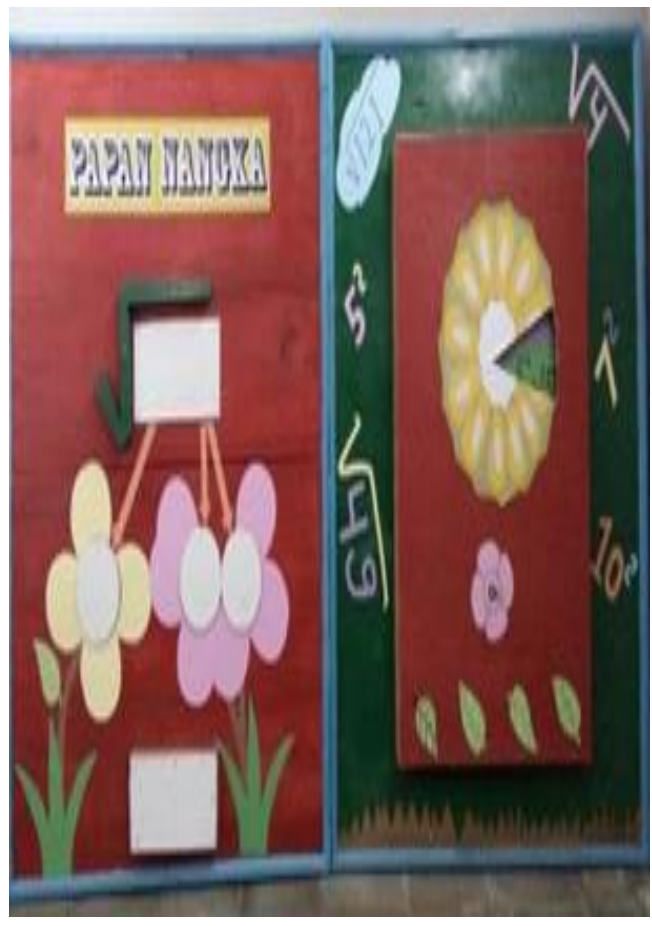

Gambar 5. Papan Nangka

Katalog alat peraga yang tersedia dapat dilihat pada gambar berikut.

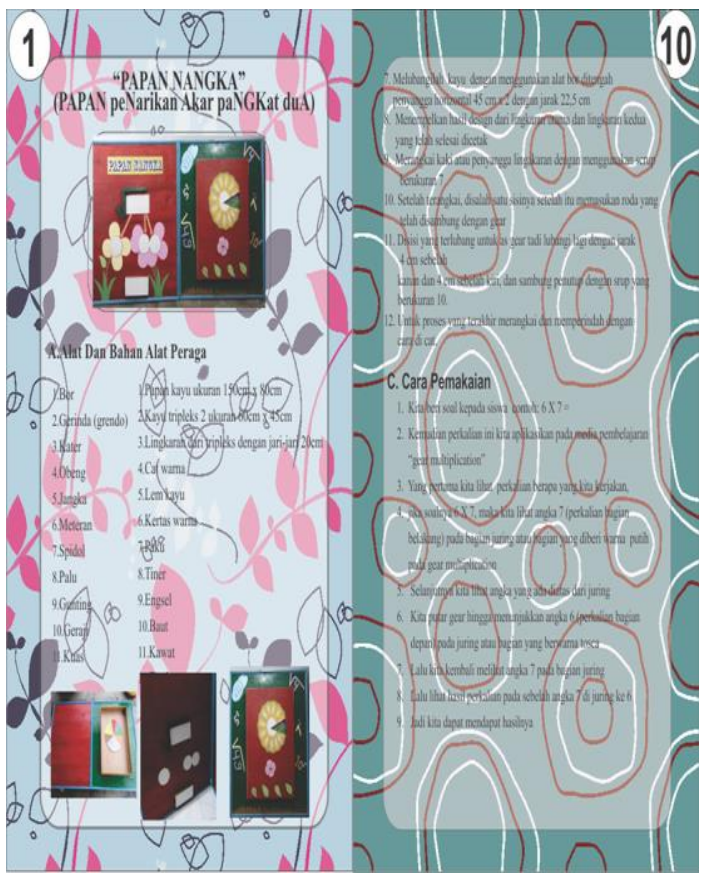

Gambar 6. Katalog Papan Nangka

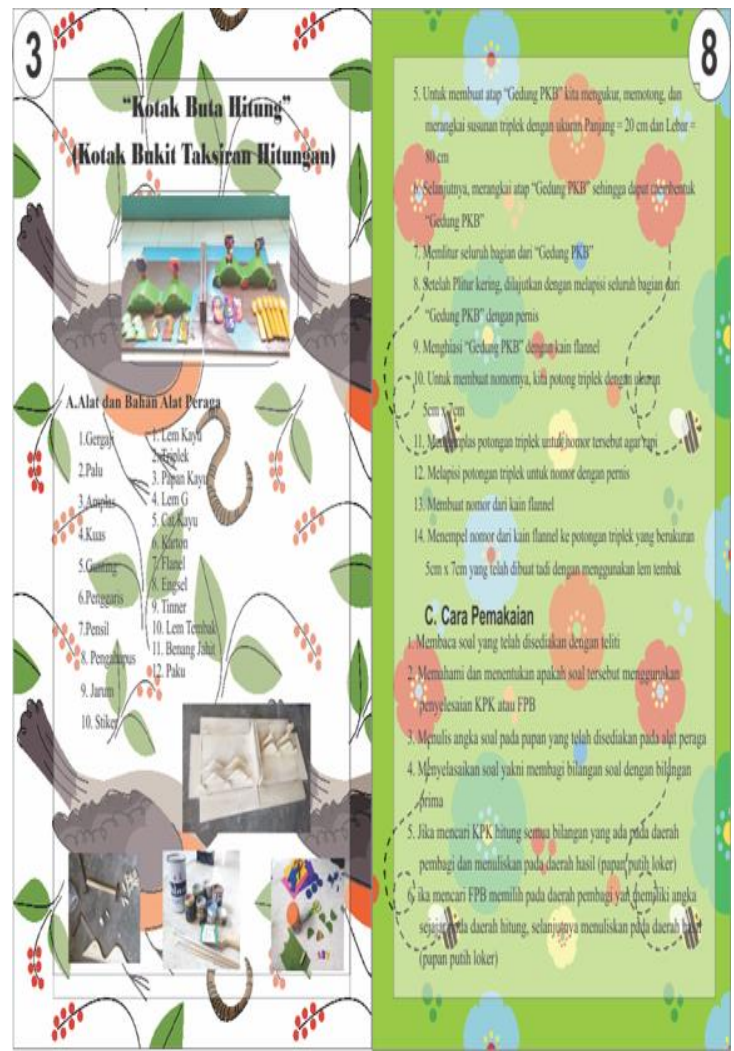

Gambar 7. Katalog Kotak Buta Hitung 
PRINSIP Pendidikan Matematika

Volume 2, Nomor 1, November 2019

\section{SIMPULAN}

Adapun simpulan setelah kegiatan dilaksanakan adalah sebagai berikut.

a) Program yang dilaksanakan berjalan baik dan lancar. Program ini mampu meningkatkan motivasi guru SD di kecamatan Pungging kabupaten Mojokerto dalam pembuatan alat- alat peraga interaktif.

b) Adanya peningkatan pengetahuan dan keterampilan para guru tentang pembuatan media pembelajaran matematika interaktif.

c) Tersedianya media pembelajaran matematika interaktif yang menarik di tingkat sekolah dasar.

d) Setelah melakukan pelatihan ini, guru diharapkan senantiasa mengembangkan kemampuan beserta pemahamannya terkait perkembangan dan penerapan media pembelajaran.

\section{DAFTAR PUSTAKA}

Ibrahim dan Suparni. (2009). Strategi pembelajaran matematika. Yogyakarta: Teras.

Masamah, U. (2017). Retensi kemampuan berpikir reflektif melalui pembelajaran berbasis masalah ditinjau dari kemampuan awal matematika siswa MAN Ngawi. Jurnal Konstanta, 1(1), 51 - 72.

Murdiyanto, T., dan Mahatma, Y. (2014). Pengembangan alat peraga matematika untuk meningkatkan minat dan motivasi belajar matematika siswa sekolah dasar. Jurnal Sarwahita, 11(1), 38 - 43 